\title{
PENGARUH PERPUTARAN KAS, PERPUTARAN PIUTANG, DAN PERPUTARAN PERSEDIAAN TERHADAP PRDFITABILITAS (Studi Empiris Pada Perusahaan Manufaktur Sektor Barang Konsumsi yang Terdaftar di Bursa Efek Indanesia (BEI) Periode 2016-2019)
}

\author{
Jadongan Sijabat', Monica Indriyani Sijabat ${ }^{2}$ \\ Fakultas Ekonami dan Bisnis Universitas HKBP Nommensen, Medan \\ jadongansijabat回uhn.ac.id
}

\begin{abstract}
Info Artikel
Diterima : 5 Maret 2021

Revisi : 12 April 2021

Terbit : : 28 Juni 202।
\end{abstract}

\section{Key wards:}

Cash Turnaver, Accuunts

Receivable Turnover, Inventory

Turnover, Prafitability, and

Return on Assets (RDA)

\section{Kata Kunci:}

Perputaran Kas, Perputaran

Piutang, Perputaran Persediaan,

Profitabilitas, dan Return un

Asset (R】A)

\section{Corresponding Authar :}

Jadangan Sijabat, E-mail:

jadangansijabat国uhn.ac.id

\section{Abstract}

Profitability is the company's ability to earn a profit. One of the factors that can affect the profitability of a company is financial ratio. The population in this study is the consumer goods industry sectar, which number as many as 53 companies. The results of this study indicate that partially cash turnover has no significant negative effect on Return on Assets (RDA), accounts receivable turnover has a positive and significant effect on Return on Assets (RDA), inventory turnover has no significant pasitive effect on Return on Assets (RDA). The results simultaneously explain that cash turnover, accounts receivable turnover, and inventory turnover have a significant effect on RDA in manufacturing companies in the consumer gouds industry listed on the Indonesia Stack Exchange. The Adjusted R Square value

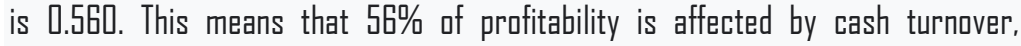
accounts receivable turnover, and inventory turnaver. While the remaining 44\% is influenced by other factors not examined in this study.

\section{Abstrak}

Profitabilitas merupakan kemampuan perusahaan dalam memperoleh laba. Salah satu faktor yang dapat mempengaruhi profitabilitas pada suatu perusahaan adalah rasio keuangan. Populasi dalam penelitian ini adalah sektor industri barang konsumsi, yang jumlahnya sebanyak 53 perusahaan. Sampel penelitian ini berjumlah 30 perusahaan yang diambil berdasarkan teknik purpasive sampling. Hasil penelitian ini menunjukkan bahwa secara parsial perputaran kas berpengaruh negatif tidak signifikan terhadap Return on Asset (RDA), perputaran piutang berpengaruh positif dan signifikan terhadap Return on Asset (RDA), perputaran persediaan berpengaruh pasitif tidak signifikan terhadap Return un Asset (RDA). Hasil secara simultan menjelaskan bahwa perputaran kas, perputaran piutang, dan perputaran persediaan berpengaruh signifikan terhadap RDA pada perusahaan manufaktur sektor industri barang konsumsi yang terdaftar di Bursa Efek Indonesia. Nilai Adjusted R Square adalah 0,560. Hal ini berarti 56 \% profitabilitas dipengaruhi oleh perputaran kas, perputaran piutang, dan perputaran persediaan. Sedangkan sisanya $44 \%$ dipengaruhi oleh faktor-faktor lain yang tidak diteliti dalam penelitian ini. 


\section{PENDAHULUAN}

Dalam masa persaingan pereknnomian yang semakin ketat, perusahaan diwajibkan untuk mempunyai daya saing yang kuat agar dapat mempertahankan kelangsungan hidup dan mewujudkan tujuan perusahaan. Untuk mempertahankan kelangsungan hidup dan mewujudkan tujuan perusahaan dibutuhkan suatu penanganan dan pengolahan sumber daya yang dilakukan oleh pihak manajemen dengan baik. Pihak manajemen dituntut untuk dapat mengkoordinasi penggunaan sumber daya yang dimiliki perusahaan secara efisien dan efektif, selain itu juga dituntut untuk dapat menghasilkan keputusan-keputusan yang menunjang pencapaian tujuan perusahaan dimasa yang akan datang. Tujuan akhir yang ingin dicapai suatu perusahaan yang terpenting adalah memperoleh laba atau keuntungan yang maksimal (Kasmir, 2016). Dengan memperoleh laba yang maksimal seperti yang telah ditargetkan, perusahaan dapat mengukur tingkat keuntungannya dengan menggunakaan rasio profitabilitas.

Return Dn Assets (RDA) adalah salah satu bentuk dari rasio profitabilitas yang dimaksudkan untuk dapat mengukur kemampuan perusahaan dengan keseluruhan dana yang ditanam dalam aktiva yang digunakan untuk operasi perusahaan dalam menghasilkan keuntungan. Semakin besar rasio ini maka semakin baik. Analisis RDA dalam menganalisa keuangan mempunyai arti yang sangat penting sebagai salah satu teknik yang bersifat menyeluruh. Artinya analisa RDA ini sudah merupakan teknik analisa yang umum digunakan oleh pimpinan perusahaan untuk mengukur efektifitas dari keseluruhan operasi perusahaan. Salah satu yang mempengaruhi tinggi rendahnya profitabilitas adalah modal kerja.

Menurut (Kasmir, 20IC), madal kerja didefenisikan sebagai madal yang digunakan untuk membiayai operasional perusahaan sehari-hari, terutama yang memiliki jangka waktu pendek. Dengan kata lain dapat diartikan, modal kerja adalah jumlah dana yang digunakan selama periode akuntansi yang dimaksudkan untuk menghasilkan pendapatan jangka pendek saja yaitu berupa kas, piutang, dan persediaan.

Kas merupakan aktiva yang paling likuid (lancar) yang dimiliki perusahaan. Kas akan diurut sebagai komponen pertama dari aktiva lancar dalam neraca. Tujuan dari kas adalah untuk membiayai operasi perusahaan sehari-hari maupun untuk mengadakan investasi baru dalam aktiva tetap. Untuk melihat berapa kali kas berputar dalam satu periode tertentu dalam menghasilkan pendapatan dapat ditunjukkan dengan menghitung perputaran kas.

Perputaran Kas (cash turnaver) berfungsi untuk mengukur tingkat kecukupan madal kerja perusahaan yang dibutuhkan untuk membayar tagihan dan membiayai penjualan. Artinya rasio ini digunakan untuk mengukur tingkat ketersediaan kas untuk membayar tagihan (utang) dan biaya-biaya yang berkaitan dengan penjualan. Semakin besar kas yang ada pada perusahaan berarti semakin tinggi tingkat likuiditas perusahaan. Ini berarti bahwa perusahaan dapat memenuhi segala kewajiban yang ada dan dapat lebih cepat dalam menentukan kebijakan yang berhubungan dengan finansial perusahaan karena kas merupakan elemen yang paling mudah diterima dalam transaksi dan operasional. Dengan menghitung tingkat perputaran kas akan dapat diketahui sampai sejauh mana tingkat efisiensi perusahaan dalam mengelola kas untuk mencapai tujuan dari perusahaan itu sendiri yaitu kemampuan perusahaan tersebut menghasilkan laba. RDA merupakan rasio yang menunjukkan keefisiensian perusahaan dalam mengelola seluruh aktiva, berarti semakin tinggi efisiensi penggunaan kasnya maka keuntungan yang diperaleh akan semakin besar. 
Piutang merupakan bagian dari aktiva lancar yang merupakan bukti dari adanya penjualan kredit. Penjualan kredit inilah yang menimbulkan piutang atau taghan. Semakin besar penjualan kredit maka semakin besar pula investasi dalam piutang dan akibatnya risikn atau biaya yang akan dikeluarkan akan semakin besar pula. Piutang merupakan hak untuk menagih sejumlah uang dari penjual kepada pembeli yang timbul karena adanya suatu transaksi. Untuk mengukur berapa lama penagihan piutang selama satu periode dapat dilihat dari perputaran piutang. Perputaran piutang (receivable turnover) berfungsi untuk memperkirakan berapa kali dalam satu periode tertentu jumlah kas yang masuk ke perusahaan yang diperoleh dari piutang itu sendiri.

Masalah piutang menjadi penting manakala perusahaan harus menilai dan mempertimbangkan berapa besarnya jumlah piutang yang optimal. Mengingat pentingnya suatu piutang tersebut, piutang perusahaan harus dikelola secara efisien dengan biaya-biaya yang ditimbulkan karena adanya piutang. Oleh karena itu setiap perusahaan mengambil kebijakan untuk memberikan kredit yang sudah ditetapkan dan diharapkan untuk para konsumen atau pelanggan agar mereka membayar utang tepat pada waktu yang telah ditentukan. Piutang merupakan suatu bentuk investasi yang cukup besar bagi perusahaan dan memberikan banyak manfaat bagi perusahaan, maka diperlukan adanya manajemen piutang yang lebih baik sehingga keuntungan yang didapatkan lebih meningkat. Selain itu piutang juga dapat mengukur kemampuan perusahaan dengan keseluruhan dana atau modal yang ditanamkan dalam aktiva yang digunakan untuk operasi perusahaan dan menghasilkan keuntungan atau laba yang besar bagi perusahaan. Untuk dapat mengetahui seberapa besar perusahaan mampu menghasikan laba, maka digunakan suatu analisis rasio keuangan yaitu RDA. Rasio ini menggambarkan perputaran asset yang diukur dari volume penjualan kredit. Semakin besar rasionya maka semakin baik. Berarti aktiva dapat cepat meraih laba dengan menggunakan tingkat perputaran piutang.

Persediaan merupakan investasi yang paling besar dalam aktiva lancar untuk sebagian besar perusahaan manufaktur. Persediaan diperlukan untuk dapat melakukan proses produksi sehingga penjualan dapat berjalan lancar. Untuk mengukur berapa kali dana yang tertanam dalam persediaan akan berputar dalam satu periode atau berapa lama rata-rata persediaan tersimpan di gudang hingga akhirnya terjual dapat dilihat dengan menghitung perputaran persediaan.

Perputaran Persediaan (inventary turnover) berfungsi untuk mengukur perjalanan persediaan sampai kembali menjadi kas. Perputaran persediaan merupakan rasio yang digunakan mengukur berapa kali dana yang ditanam dalam persediaan ini berputar dalam satu periode tertentu biasanya dalam kurun waktu satu tahun. Apabila rasio yang diperoleh tinggi, ini menunjukkan perusahaan bekerja secara efisien dan likuid persediaan semakin baik. Demikian pula apabila perputaran persediaan rendah berarti perusahaan bekerja secara tidak efisien atau tidak produktif dan banyak barang persediaan yang menumpuk.

Untuk mengetahui bagaimana hubungan perputaran persediaan terhadap Return Dn Asset (RDA). Salah satu teari tentang persediaan mengemukakan bahwa persediaan merupakan aktiva yang harus dikelola dengan baik, kesalahan dalam pengelolaan akan mengakibatkan komponen aktiva lain menjadi tidak optimal, bahkan bisa mengakibatkan kerugian. Pengelolaan persediaan merupakan suatu pekerjaan yang sulit dan pengelolaan perputaran persediaan ini sangat menentukan dalam manajemen kelanjutan aktivitas perusahaan. Untuk dapat mengetahui seberapa besar perusahaan mampu menghasilkan laba, maka digunakan suatu analisis rasio keuangan yaitu RDA. Rasio ini menggambarkan perputaran asset yang diukur dari volume penjualan. Bila 
semakin besar rasio ini makan semakin baik hasilnya. Hal ini berarti bahwa aktiva dapat lebih cepat berputar dan meraih laba dengan menggunakan tingkat perputaran persediaan.

Berdasarkan uraian latar belakang diatas terdapat fenomena bahwa kas, piutang, dan persediaan merupakan madal kerja yang menjadi faktor utama untuk melihat perusahaan tersebut berjalan dengan efektif dan efisien. Hal ini juga menjadi tolak ukur pihak luar seperti investor yang ingin menanamkan sahamnya pada suatu perusahaan dengan melihat perputaran kas, perputaran piutang, dan persediaan pada laparan keuangannya. Jika semakin tinggi perputarannya maka laba atau prafitabilitas yang dihasilkan akan semakin baik pula.

Perusahaaan Manufaktur merupakan perusahaan yang bergerak di bidang pembuatan produk. Perusahaan manufaktur terdiri dari tiga sektor yaitu : Industri Dasar Kimia, Sektor Aneka Industri, dan Sektor Industri Barang Konsumsi. Penelitian ini secara spesifik dilakukan pada perusahaan manufaktur sektor industri barang komsumsi yang pada penelitian sebelumnya belum dilakukan. Dipilihnya perusahaan sektor industri barang konsumsi karena merupakan kategori perusahaan industri manufaktur yang produknya sangat dibutuhkan masyarakat, sehingga prospeknya menguntungkan baik masa sekarang maupun masa yang akan datang. Barang konsumsi menjadi industri yang penting bagi perkembangan perekonamian bangsa. Hal ini tidak terlepas dari perusahaan yang bergerak dalam industri barang konsumsi di Indonesia. Tidak bisa dipungkiri bahwasanya dalam proses produksi barang knnsumsi dibutuhkan banyak sumber daya termasuk di dalamnya sumber daya manusia. Industri barang konsumsi mempunyai peranan dalam menyerap tenaga kerja dan meningkatkan pendapatan pada suatu negara.

Menurut penelitian terdahulu yang dilakukan oleh (Dilla Ramadani dan Rasyeni Rasyid, 2019) menyatakan bahwa: perputaran kas berpengaruh positif signifikan terhadap profitabilitas yang diukur melalui RDA yang memiliki nilai koefisien positif. Hasil penelitian yang sama menyatakan perputaran piutang berpengaruh positif signifikan terhadap profitabilitas yang diukur dengan RDA yang memiliki nilai koefisien positif. Peneliti ini juga membuktikan perputaran persediaan berpengaruh positif tidak signifikan terhadap profitabilitas yang diukur melalui RDA yang memiliki nilai kaefisien positif. Selanjutnya menurut penelitian terdahulu yang dilakukan oleh (Indah Risky Purwaningtias, 2019) menyatakan perputaran kas tidak mempunyai pengaruh terhadap profitabilitas perusahaan karena tingkat signifikansi yang lebih besar. Hasil penelitian yang sama menyatakan perputaran piutang tidak berpengaruh terhadap profitabilitas perusahaan. Peneliti ini juga membuktikan dari hasil pengujian perputaran persediaan tidak berpengaruh terhadap profitabilitas pada perusahaan.

Karena masih ditemukannya riset gap berdasarkan penelitian terdahulu, maka yang menjadi tujuan penelitian ini dirumuskan sebagai berikut:

1. Untuk mendapatkan bukti empiris tentang pengaruh perputaran kas terhadap profitabitas (RDA) pada perusahaan manufaktur sektor barang konsumsi yang terdaftar di Bursa Efek Indanesia.

2. Untuk mendapatkan bukti empiris tentang pengaruh perputaran piutang terhadap prafitabitas (RDA) pada perusahaan manufaktur sektor barang konsumsi yang terdaftar di Bursa Efek Indanesia.

3. Untuk mendapatkan bukti empiris tentang pengaruh perputaran persediaan terhadap profitabitas (RDA) pada perusahaan manufaktur sektar barang konsumsi yang terdaftar di Bursa Efek Indanesia. 


\section{LANDASAN TEDRI DAN HIPDTESIS Profitabilitas}

Perusahaan adalah sebuah organisasi yang beroperasi dengan tujuan menghasilkan keuntungan, dengan cara menjual produk (barang dan atau jasa) kepada para pelanggannya. Menurut (Lukman Syamsuddin, 2007) keuntungan perusahaan dapat ditingkatkan dengan dua cara: meningkatkan penjualan (baik volume maupun harga jual) dan menekan biaya. Tujuan operasional dari sebagian besar perusahaan adalah untuk memaksimalisasi profit, baik profit jangka pendek maupun profit jangka panjang. Untuk itu manajemen dituntut untuk meningkatkan return bagi pemilik perusahaan, sekaligus juga meningkatkan kesejahteraan karyawan. Dimana alat untuk mengukur tingkat efektivitas kinerja manajemen digunakan adalah rasio profitabilitas.

Rasio profitabilitas dapat digunakan untuk mengevaluasi keuntungan perusahaan sehubungan dengan tingkat penjualan tertentu, tingkat aktiva tertentu dan tingkat modal tertentu. Tanpa keuntungan, perusahaan tidak bisa menarik modal dari kreditur dan pemilik. Menurut Al. Haryono Jusup (201I), rasio profitabilitas merupakan alat untuk mengukur laba dan keberhasilan operasi suatu perusahaan dalam suatu periade waktu tertentu. Dari pengertian beserta penjelasan diatas, profitabilitas mempunyai arti penting dalam kegiatan usaha untuk mempertahankan kelangsungan hidupnya dalam jangka panjang, karena profitabilitas menunjukkan perusahaan tersebut mempunyai prospek yang baik di masa yang akan datang. Dengan demikian setiap perusahaan akan selalu berusaha meningkatkan profitabilitasnya, karena semakin tinggi tingkat profitabilitasnya, maka kelangsungan kegiatan usaha perusahaan tersebut akan terus terjamin. Rasio profitabilitas yang digunakan dalam penelitian ini adalah Return Dn Assets (RDA).

\section{Return Dn Asset}

Return Dn Assets (RDA) yang sering disebut juga Return Dn Investment merupakan salah satu rasio profitabilitas. Dalam analisis laporan keuangan, rasio ini sering dilihat karena dapat menunjukkan keberhasilan perusahaan dalam menghasilkan keuntungan. RDA mampu mengukur kemampuan perusahaan menghasilkan keuntungan pada masa lampau untuk kemudian diprayeksikan dimasa yang akan datang. Asset atau aktiva yang dimaksud adalah keseluruhan harta perusahaan yang diperoleh dari modal sendiri maupun modal asing yang telah diubah perusahaan menjadi aktiva-aktiva perusahaan untuk kelangsungan hidup perusahaan.

Menurut Hery (2DI5), hasil pengembalian atas aset (RDA) merupakan rasio yang menunjukkan seberapa besar kontribusi aset dalam menciptakan laba bersih. Dengan kata lain, rasio ini digunakan untuk mengukur seberapa besar jumlah laba bersih yang akan dihasilkan dari setiap rupiah dana yang tertanam dalam total aset yang dimiliki perusahaan untuk melakukan aktivitas perusahaan secara keseluruhan. Semakin tinggi hasil pengembalian atas aset berarti semakin tinggi pula jumlah laba bersih yang dihasilkan dari setiap rupiah dana yang tertanam dalam total aset. Besarnya RDA akan berubah jika ada perubahan laba bersih atau total aset, baik masing-masing atau kedua-duanya. Dengan demikian maka pimpinan perusahaan dapat menggunakan salah satu atau kedua-duanya dalam rangka usaha untuk memperbesar RDA.

Return Dn Assets (RDA) yang sering disebut juga Return Dn Investment merupakan salah satu rasio profitabilitas. Dalam analisis laporan keuangan, rasio ini sering dilihat karena dapat menunjukkan keberhasilan perusahaan dalam menghasilkan keuntungan. RDA mampu mengukur kemampuan perusahaan menghasilkan keuntungan pada masa lampau untuk kemudian diprayeksikan dimasa yang akan datang. Assetatau aktiva yang 
dimaksud adalah keseluruhan harta perusahaan yang diperoleh dari modal sendiri maupun modal asing yang telah diubah perusahaan menjadi aktiva-aktiva perusahaan untuk kelangsungan hidup perusahaan.

Menurut Hery (20I5), hasil pengembalian atas aset (RDA) merupakan rasio yang menunjukkan seberapa besar knntribusi aset dalam menciptakan laba bersih. Dengan kata lain, rasio ini digunakan untuk mengukur seberapa besar jumlah laba bersih yang akan dihasilkan dari setiap rupiah dana yang tertanam dalam total aset yang dimiliki perusahaan untuk melakukan aktivitas perusahaan secara keseluruhan. Semakin tinggi hasil pengembalian atas aset berarti semakin tinggi pula jumlah laba bersih yang dihasilkan dari setiap rupiah dana yang tertanam dalam total aset. Besarnya RDA akan berubah jika ada perubahan laba bersih atau total aset, baik masing-masing atau kedua-duanya. Dengan demikian maka pimpinan perusahaan dapat menggunakan salah satu atau kedua-duanya dalam rangka usaha untuk memperbesar RDA.

\section{Perputaran Kas}

Kas merupakan unsur modal kerja yang paling tinggi tingkat likuiditasnya. Makin besar jumlah kas yang ada dalam perusahaan berarti makin tinggi tingkat likuiditasnya. Berarti perusahaan mempunyai resiko yang lebih kecil dalam memenuhi kewajban finansialnya. Tetapi tidak berarti bahwa perusahaan harus mempertahankan uang kas dalam jumlah yang relatif besar, karena semakin besar kas maka semakin banyak uang yang menganggur sehingga akan memperkecil profitabilitas. Perputaran kas merupakan perbandingan antara penjualan bersih dengan jumlah rata-rata kas. Rahma (201I) dalam (Nina Sufiana dan Ni Ketut Purnawati, 2013) menyatakan bahwa perputaran kas menunjukkan kemampuan kas dalam menghasilkan pendapatan, sehingga dapat dilihat berapa kali uang kas berputar dalam satu periode tertentu. Semakin tinggi perputaran kas ini akan semakin baik, ini berarti semakin tinggi efisiensi penggunaan kasnya dan keuntungan yang diperoleh akan semakin besar. Rasio perputaran kas (cash turnover) berfungsi untuk mengukur tingkat kecukupan modal kerja perusahaan yang dibutuhkan untuk membayar tagihan dan membiayai penjualan. Artinya rasio ini digunakan untuk mengukur tingkat ketersediaan kas untuk membayar tagihan (utang) dan biaya-biaya yang berkaitan dengan penjualan.

\section{Perputaran Piutang}

Sebagian besar piutang timbul dari penyerahan barang dan jasa secara kredit kepada pelanggan. Tidak dapat dipungkiri bahwa umumnya pelanggan akan menjadi lebih tertarik untuk membeli sebuah produk yang ditawarkan secara kredit oleh perusahaan dan hal ini ternyata menjadi salah satu trik bagi perusahaan untuk meningkatkan besarnya omset penjualan yang akan tampak dalam laporan laba ruginya. Pasisi piutang dan taksiran pengumpulannya dapat dinilai dengan menghitung tingkat perputaran piutang tersebut, yaitu dengan membagi total penjualan kredit dengan piutang rata-rata yaitu saldo awal tahun piutang ditambah saldo akhir tahun piutang dibagi dua.

Menurut Hery (2015), perputaran Piutang usaha merupakan rasio yang digunakan untuk mengukur berapa kali dana yang tertanam dalam piutang usaha akan berputar dalam satu periode atau berapa lama (dalam hari) rata-rata penagihan piutang usaha. Rasio ini menggambarkan seberapa cepat piutang usaha berhasil ditagih menjadi kas. Semakin tinggi rasio perputaran piutang usaha menunjukkan bahwa saldo modal kerja yang tertanam dalam piutang usaha semakin kecil dan hal ini berarti semakin baik perusahaan.

Dikatakan semakin baik karena lamanya penagihan piutang usaha semakin cepat, atau dalam arti piutang usaha dapat ditagih dalam jangka waktu yang relatif semakin singkat sehingga dapat segera dicairkan 
menjadi uang atau kas, hal ini berarti keuntungan perusahaan dapat lebih cepat diterima. Sebaliknya, semakin rendah rasio perputaran piutang usaha menunjukkan bahwa modal kerja yang tertanam dalam piutang usaha semakin besar (aver investment) dan hal ini berarti semakin tidak baik bagi perusahaan. Dikatakan semakin tidak baik karena lamanya penagihan piutang usaha semakin panjang, atau dengan kata lain piutang usaha tidak dapat ditagh dalam waktu yang relatif sehingga butuh waktu yang lama menunggu untuk dapat dicairkan menjadi uang atau kas.

\section{Perputaran Persediaan}

Persediaan merupakan unsur dari aktiva lancar yang merupakan unsur yang aktif dalam operasi perusahaan yang secara terus menerus diperoleh, diubah dan kemudian dijual kepada konsumen. Untuk mempercepat pengembalian kas melalui penjualan maka diperlukan suatu perputaran persediaan yang baik. Dalam mengevaluasi posisi persediaan, maka prosedur yang sama seperti dalam mengevaluasi piutang dapat digunakan yaitu dengan menghitung tingkat perputaran dari persediaan tersebut. Menurut Hery (2015), perputaran persediaan merupakan rasio yang digunakan untuk mengukur berapa kali dana yang tertanam dalam persediaan akan berputar dalam satu periode atau berapa lama (dalam hari) rata-rata persediaan tersimpan di gudang hingga akhirnya terjual.

Rasio ini menggambarkan seberapa cepat persediaan barang dagangan berhasil dijual kepada pelanggan. Semakin tinggi rasio perputaran persediaan menunjukkan bahwa modal kerja yang tertanam dalam persediaan barang dagang semakin kecil dan hal ini berarti semakin baik bagi perusahaan. Dikatakan semakin baik karena lamanya penjualan persediaan barang dagangan semakin cepat. Dengan kata lain bahwa persediaan barang dagang dapat dijual dalam jangka waktu yang semakin singkat sehingga dana yang tertanam dalam persediaan dapat dengan cepat dicairkan menjadi uang atau kas, hal itu berarti keuntungan/laba perusahaan dapat lebih cepat diterima. Sebaliknya, semakin rendah rasio perputaran persediaan menunjukkan bahwa modal kerja yang tertanam dalam persediaan barang dagang semkain besar (over investment) dan hal ini berarti semakin tidak baik bagi perusahaan. Dikatakan semakin tidak baik karena lamanya penjualan persediaan barang dagangan semakin panjang. Dengan kata lain bahwa persediaan barang dagangan tidak dapat dijual dalam jangka waktu yang semakin singkat sehingga dana yang tertanam dalam persediaan tidak dapat dengan cepat dicairkan menjadi uang atau kas. Perputaran persediaan yang rendah juga mengakibatkan persediaan menumpuk dan biaya penyimpanan bertambah sehingga akan menurunkan laba perusahaan.

\section{Penelitian Terdahulu}

Irman Deni (2012) meneliti pengaruh perputaran kas, perputaran piutang, dan perputaran persediaan terhadap profitabilitas pada perusahaan manufaktur yang terdaftar di Bursa Efek Indanesia tahun 2009-20II. Hasil penelitian menunjukkan bahwa secara parsial perputaran kas berpengaruh negatif dan signifikan terhadap RDA, sedangkan perputaran piutang dan perputaran persediaan berpengaruh positif dan signifikan terhadap RDA.

Eka Ayu Rahayu (2014) meneliti pengaruh perputaran kas, perputaran piutang, dan perputaran persediaan terhadap profitabilitas perusahaan manufaktur tahun 2008-20I2. Hasil penelitian menunjukkan bahwa perputaran kas, perputaran piutang dan perputaran persediaan berpengaruh secara simultan terhadap profitabilitas. Sedangkan secara parsial perputaran kas dan perputaran piutang tidak berpengaruh signifikan 
terhadap profitabilitas, hanya perputaran persediaan yang berpengaruh signifikan terhadap profitabilitas pada perusahaan manufaktur.

Mohamad Tejo Suminar (2015) meneliti pengaruh perputaran persediaan, perputaran piutang dan perputaran kas terhadap profitabilitas pada perusahaan sektor industri barang konsumsi yang terdaftar di Bursa Efek Indanesia periode 2008-2013. Hasil penelitian menunjukkan bahwa secara parsial perputaran kas berpengaruh negatif terhadap RDA, sedangkan perputaran piutang dan perputaran persediaan berpengaruh positif terhadap RDA. Secara simultan perputaran kas, piutang dan persediaan secara bersama-sama berpengaruh positif terhadap RロA.

Putri Ayu Diana (2016) meneliti pengaruh perputaran kas, piutang, persediaan terhadap profitabilitas pada perusahaan semen di Bursa Efek Indanesia tahun 2015. Hasil penelitian menunjukkan bahwa perputaran kas dan perputaran persediaan berpengaruh terhadap profitabilitas sedangkan perputaran piutang tidak berpengaruh signifikan terhadap profitabilitas.

Asna Lestari (2016) meneliti analisis perputaran piutang dan perputaran persediaan serta pengaruhnya terhadap profitabilitas perusahaan otomatif yang terdaftar di Bursa Efek Indanesia periode 20ID2014. Hasil penelitian ini menunjukan bahwa variabel perputaran piutang dan perputaran persediaan tidak berpengaruh terhadap profitabilitas dan secara simultan perputaran piutang dan perputaran persediaan tidak berpengaruh signifikan terhadap profitabilitas.

Sarjita Surya, dkk (2017) meneliti pengaruh perputaran kas dan perputaran persediaan terhadap profitabilitas pada perusahaan otomatif dan kompanennya yang terdaftar di Bursa Efek Indanesia periode 20102013. Hasil penelitian menunjukkan bahwa perputaran kas dan perputaran persediaan secara simutan tidak berpengaruh terhadap profitabilitas, dan secara parsial masing-masing variabel tidak berpengaruh terhadap profitabilitas.

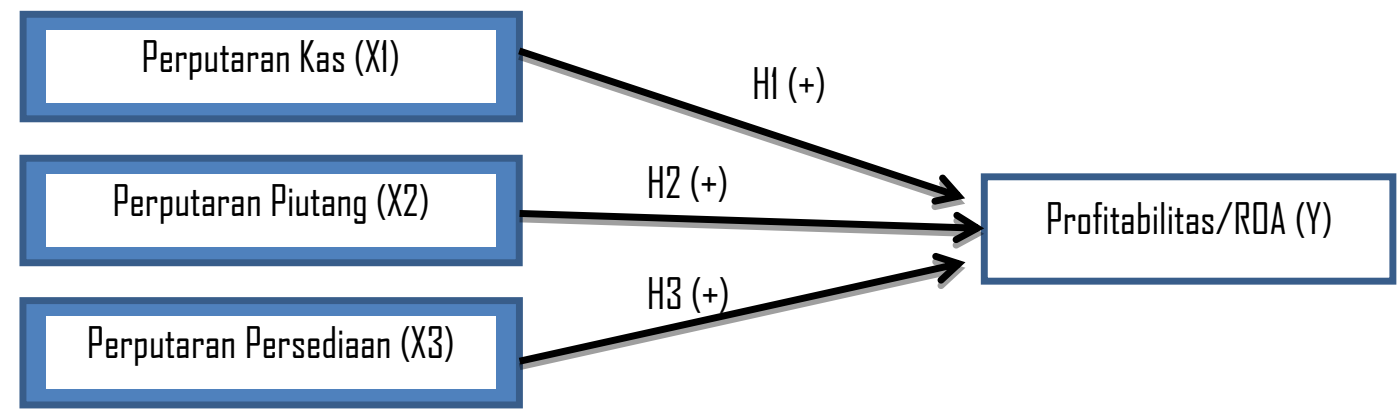

\section{Gambar 1. Kerangka Konseptual}

\section{Hipotesis Penelitian}

\section{Perputaran Kas Terhadap RDA}

Kas merupakan elemen aktiva lancar yang paling likuid, dan tingkat perputarannya merupakan indikatar apakah perusahaan mengalami keuntungan atau sebaliknya. Semakin besar kas yang ada pada perusahaan, berarti semakin tinggi tingkat likuiditas perusahaan. Ini berarti bahwa perusahaan dapat memenuhi segala kewajiban yang ada dan dapat lebih cepat dalam menentukan kebijakan yang berhubungan dengan finansial 
perusahaan karena kas merupakan elemen yang paling mudah diterima dalam transaksi dan operasional. Maka dalam hal ini, perusahaan perlu menentukan arah kebijakan mengenai perputaran kas agar tingkat liquiditas perusahaan tetap terjaga. Semakin tinggi perputaran kas ini akan semakin baik. Karena ini berarti semakin tinggi efisiensi penggunaan kasnya dan keuntungan yang diperoleh akan semakin besar (Putri Ayu Diana, 2016). Hal ini sejalan dengan hasil penelitian Putri Ayu Diana (2016) yang menunjukkan bahwa perputaran kas berpengaruh positif terhadap profitabilitas. Berdasarkan penjelasan di atas dapat dirumuskan hipotesis sebagai berikut :

$H_{1}$ : Perputaran kas berpengaruh positif signifikan terhadap RDA

\section{Perputaran Piutang Terhadap RDA}

Piutang merupakan elemen aktiva lancar yang timbul karena adanya penjualan kredit. Timbulnya piutang diharapkan bisa menjadi solusi akan permasalahan yang timbul karena pihak manajemen kesulitan untuk memaksakan penjualan tunai, sehingga piutang bisa menjadi alternatif agar persediaan bisa berputar hingga menjadi kas (Irman Deni, 20I2). Selain menjadi solusi, piutang juga bisa menjadi permasalahan apabila perputarannya tidak diawasi dengan benar. Perputaran piutang merupakan periode terikatnya madal dalam piutang yang tergantung pada syarat pembayarannya. Makin lunak atau makin lama syarat pembayarannya, berarti bahwa tingkat perputarannya selama periode tertentu akan semakin rendah. Semakin rendah rasio perputaran piutang usaha menunjukkan bahwa modal kerja yang tertanam dalam piutang usaha semakin besar (aver investment) dan hal ini berarti semakin tidak baik bagi perusahaan (Mohamad Teja Suminar, 2015). Hal ini sejalan dengan hasil penelitian Irman Deni (2012) dan Mohamad Tejo Suminar (2015) yang menunjukkan bahwa perputaran piutang berpengaruh positif terhadap profitabilitas. Berdasarkan penjelasan diatas dapat dirumuskan hipotesis sebagai berikut :

$\mathrm{H}_{2}$ : Perputaran Piutang berpengaruh pasitif signifikan terhadap RDA

\section{Perputaran Persediaan Terhadap RDA}

Persediaan merupakan aktiva lancar perusahaan yang merupakan modal kerja guna memutar rada perusahaan. Semakin tinggi rasio perputaran persediaan menunjukkan bahwa modal kerja yang tertanam dalam persediaan barang dagang semakin kecil, dan hal ini berarti semakin baik bagi perusahaan (Putri Ayu Diana, 2016). Dikatakan semakin baik karena lamanya penjualan persediaan barang dagang semakin cepat, atau dengan kata lain bahwa persediaan barang dagang dapat dijual dalam jangka waktu yang semakin singkat sehingga dana yang tertanam dalam persediaan dapat dengan cepat dicairkan menjadi uang atau kas (Mohamad Tejo Suminar, 2015).. Sebaliknya, semakin rendah rasio perputaran persediaan menunjukkan bahwa modal kerja yang tertanam dalam persediaan barang dagang semakin besar (over investment) dan hal ini berarti semakin tidak baik bagi perusahaan. Dikatakan semakin tidak baik karena lamanya penjualan persediaan barang dagang semakin panjang, atau dengan kata lain bahwa persediaan barang dagang tidak dapat dijual dalam jangka waktu yang semakin singkat sehingga dana yang tertanam dalam persediaan tidak dapat dengan cepat dicairkan menjadi uang atau kas. Hal ini sejalan dengan hasil penelitian Irman Deni (2012), Eka Ayu Rahayu (2014), Mohamad Tejo Suminar (2015), dan Putri Ayu Diana (2016) yang menunjukkan bahwa perputaran persediaan berpengaruh positif terhadap profitabilitas. Berdasarkan penjelasan di atas dapat dirumuskan hipotesis sebagai berikut: 
$\mathrm{H}_{3}$ : Perputaran Persediaan berpengaruh pasitif signifikan terhadap RDA

\section{METODOLDGI PENELITIAN}

Populasi dalam penelitian ini adalah semua perusahaan manufaktur sektor barang konsumsi yang terdaftar di Bursa Efek Indanesia (BEI) selama tahun 2016-2018 yang berjumlah 53 perusahaan. Pemilihan sampel dalam penelitian ini ditentukan dengan cara purpasive sampling. Kriteria yang dijadikan untuk penentuan sampel dalam penelitian ini adalah :

1) Perusahaan-perusahaan manufaktur sektor barang konsumsi yang terdaftar di Bursa Efek Indanesia (BEI) selama tahun 20I6 - 2019.

2) Perusahaan-perusahaan tersebut memiliki laporan keuangan (annua/ report) setiap tahun dan telah diaudit serta tidak keluar (delisting) selama tahun 2016 - 2019.

3) Perusahaan-perusahaan tersebut melaparkan laba tiap tahun selama periode penelitian 2016 - 2019.

Jenis data dalam penelitian ini adalah data kuantitatif. Data Kuantitatif adalah rasio perputaran kas, perputaran piutang, perputaran persediaan dan profitabilitas pada Perusahaan Manufaktur Sektor Barang Konsumsi yang terdaftar di Bursa Efek Indanesia Periode 2016 - 2019. Sumber data diperaleh melalui situs www.idx.ca.id. Penelitian ini menggunakan analisis linear berganda SPSS dalam analisis data.

Yang merupakan variabel terikat dalam penelitian ini adalah RDA (Y). Sedangkan yang menjadi varabel bebasnya adalah perputaran kas, perputaran piutang, dan perputaran persediaan.

\section{Return Dn Assets (Y)}

Return Dn Assets (RDA) merupakan rasio yang menunjukkan seberapa besar kontribusi aset dalam menciptakan laba bersih. Dengan kata lain, rasio ini digunakan untuk mengukur seberapa besar jumlah laba bersih yang akan dihasilkan dari setiap rupiah dana yang tertanam dalam total aset. Persamaan disajikan sebagai berikut:

$$
\text { ROA }=\frac{\text { Laba Bersih }}{\text { Total Aset }}
$$

\section{Perputaran Kas $\left(X_{1}\right)$}

Perputaran kas (cash turnover) merupakan rasio yang digunakan untuk mengukur ketersediaan kas untuk membayar tagihan (utang) dan biaya-biaya yang berkaitan dengan penjualan. Rata-rata kas yaitu kas awal tahun ditambah kas akhir tahun dibagi dua.

$$
\text { Perputaran Kas }=\frac{\text { Penjualan Bersih }}{\text { Rata }- \text { rata Kas }}
$$

\section{Perputaran Piutang $\left(X_{2}\right)$}

Perputaran piutang merupakan rasio yang digunakan untuk mengukur berapa kali dana yang tertanam dalam piutang akan berputar dalam satu periode atau berapa lama (dalam hari) rata-rata penagihan piutang usaha. Rasio ini menggambarkan seberapa cepat piutang usaha berhasil ditagih menjadi kas. Persamaan disajikan sebagai berikut: 


$$
\text { Perputaran Piutang }=\frac{\text { Penjualan Kredit }}{\text { (Piutang Awal tahun+Piutang Akhir }): 2}
$$

\section{Perputaran Persediaan $\left(X_{3}\right)$}

Perputaran persediaan merupakan rasio yang digunakan untuk mengukur berapa kali dana yang tertanam dalam persediaan akan berputar dalam satu periode, atau berapa lama (dalam hari) rata-rata persediaan tersimpan di gudang hingga akhirnya terjual. Rasio ini menggambarkan seberapa cepat persediaan barang dagangan berhasil dijual kepada pelanggan. Persamaan disajikan sebagai berikut:

$$
\begin{aligned}
& \text { Perputaran Persediaan } \\
& =\frac{\text { Harga Pokok Penjualan }}{(\text { Persediaan Awal tahun }+ \text { Persediaan Akhir Tahun }): 2}
\end{aligned}
$$

\section{HASIL DAN PEMBAHASAN}

\section{Lji Regresi Linear Berganda}

Model pengujian melalui regresi berganda dilakukan untuk menganalisa Perputaran Kas, Perputaran Piutang, Perputaran Persediaan dan Return On Asset (RDA).

\section{Tabel I. Uji F}

ANDVAa

\begin{tabular}{|ll|r|r|r|r|r|}
\hline Model & Sum of Squares & Df & Mean Square & F & Sig. \\
\hline \multirow{4}{*}{1} & Regression & .035 & 3 & .012 & 2.832 & $.043^{b}$ \\
& Residual & .370 & 89 & .004 & & \\
& Total & .405 & 92 & & & \\
\hline
\end{tabular}

a. Dependent Variable: Return Dn Asset

b. Predictors: (Constant), PerputaranPersediaan, PerputaranKas, PerputaranPiutang

Berdasarkan hasil analisis regresi berganda uji F diperoleh nilai signifikansi sebesar 0,043 lebih kecil dari $\alpha=0$, Q5. Hal ini menunjukkan bahwa secara simultan variable Perputaran Kas (XI). Perputaran Piutang (XZ) dan Perputaran Persediaan (X3) berpengaruh signifikan terhadap Return Dn Asset (RDA).

\begin{tabular}{|c|c|c|c|c|c|c|}
\hline \multirow{2}{*}{\multicolumn{2}{|c|}{ Madel }} & \multicolumn{2}{|c|}{ Unstandardized Caefficients } & \multirow{2}{*}{$\begin{array}{l}\text { Standardized } \\
\text { Coefficients } \\
\text { Beta }\end{array}$} & \multirow[t]{2}{*}{$\mathrm{t}$} & \multirow[t]{2}{*}{ Sig. } \\
\hline & & $B$ & Std. Eгror & & & \\
\hline \multirow{5}{*}{1} & (Canstant) & .073 & .018 & & 3.986 & .000 \\
\hline & Perputaran Kas & 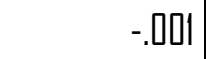 & .000 & -.188 & -1.803 & .075 \\
\hline & Peгputaran Piutang & .004 & .002 & .251 & 2.319 & .023 \\
\hline & Рeгputaran & .002 & .002 & .065 & .616 & .540 \\
\hline & Persediaan & & & & & \\
\hline
\end{tabular}

Tabel 2. Uji-t

Coefficients ${ }^{\mathrm{a}}$

Pengaruh Perputaran Kas, Perputaran Piutang, Dan Perputaran Persediaan Terhadap Prafitabilitas 
a. Dependent Variable: Return On Asset

Berdasarkan tabel 2 diatas, maka dapat dirumuskan persamaan regresi linier berganda sebagai berikut:

Return Dn Assets = 0.073 - 0.00I Perputaran Kas + 0.004 Perputaran Piutang + 0.002 Perputaran Persediaan, dengan derajat kepercayaan sebesar 5\% atau 0,05.

\section{Pengaruh Perputaran Kas Terhadap Return On Asset}

Berdasarkan hasil analisis regresi berganda diperoleh nilai koefisien regresi sebesar -0,00। dan nilai signifikansi sebesar 0,075 lebih besar dari $\alpha=$ =, (5. Hal ini menunjukkan variabel perputaran kas berpengaruh negatif tidak signifikan terhadap return an asset (RDA). Dengan demikian maka keputusan yang diambil yaitu menolak hipatesis I. Teari yang menyatakan bahwa semakin besar kas yang ada dalam perusahaan maka akan semakin tinggi pula tingkat likuiditasnya tidak terbukti. Temuan penelitian ini sejalan dengan penelitian yang dilakukan oleh Mohammad Tejo Suminar (2015) yang menyatakan bahwa perputaran kas berpengaruh negatif dan tidak signifikan terhadap return an asset.

\section{Pengaruh Perputaran Piutang Terhadap Return Dn Asset}

Berdasarkan hasil analisis regresi berganda diperoleh nilai koefisien regresi sebesar 0,004 dan nilai signifikasi sebesar 0,023 lebih kecil dari $\alpha=0,05$. Hal ini menunjukkan jika variabel perputaran piutang berpengaruh pasitif signifikan terhadap return on asset (RDA). Dengan demikian maka keputusan yang diambil yaitu menerima hipatesis 2. Penelitian ini sejalan dengan penelitian yang dilakukan oleh Irman Deni (20IZ) yang menyatakan bahwa perputaran piutang berpengaruh positif signifikan terhadap return an asset.

\section{Pengaruh Perputaran Persediaan Terhadap Return On Asset}

Berdasarkan hasil analisis regresi berganda diperoleh nilai knefisien regresi sebesar 0,002 dan nilai signifikansi sebesar 0,540 lebih besar dari $\alpha=0,05$. Hal ini menunjukkan jika variabel perputaran persediaan berpengaruh positif tidak signifikan terhadap return an asset (RDA). Dengan demikian maka keputusan yang diambil yaitu menolak hipotesis 3. Hasil penelitian ini sejalan dengan penelitian Putri Ayu Diana (2016) yang menyatakan bahwa perputaran persediaan berpengaruh positif dan tidak signifikan terhadap return an asset.

\section{Koefisien Determinasi $\left(\mathbb{R}^{2}\right)$}

Kaefisien determinasi $\left(R^{2}\right)$ digunakan untuk mengetahui seberapa besar faktor independen dapat menjelaskan faktor dependen. Hasil uji koefisien determinasi $\left(\mathbb{R}^{2}\right)$ dapat dilihat pada tabel 2 ini :

\section{Tabel 3. Koefisien Determinasi ( $\left.\mathbf{R}^{2}\right)$}

Model Summary

\begin{tabular}{|l|l|r|r|r|r|}
\hline Model & R & R Square & Adjusted R Square & Std. Error of the Estimate & Durbin-Watson \\
\hline 1 & $.2955^{a}$ & .687 & .560 & .06448 & 1.083 \\
\hline
\end{tabular}

a. Predictars: (Constant), PerputaranPersediaan, PerputaranKas, PerputaranPiutang

b. Dependent Variable: Return Dn Asset

Hasil perhitungan SPSS versi ZQ uji R2 diatas menunjukkan bahwa nilai Adjusted R Square sebesar 0,560 hal ini dapat diartikan bahwa Return Dn Asset adalah sebesar 56\% ditentukan oleh variabel independen dalam penelitian ini. Sedangkan sisanya sebesar 44\% (I00\% -56\%) dipengaruhi oleh variabel lain. 


\section{KESIMPULAN}

\section{Kesimpulan}

Berdasarkan hasil penelitian yang telah dijelaskan, maka dapat disimpulkan sebagai berikut :

I. Variabel perputaran kas berpengaruh negatif tidak signifikan terhadap return an asset sehingga menolak hipotesis I.

2. Variabel perputaran piutang berpengaruh positif dan signifikan terhadap return an asset sehingga menerima hipatesis 2.

3. Variabel perputaran persediaan berpengaruh pasitif tidak signifikan terhadap return an asset sehingga menolak hipatesis 3 .

4. Berdasarkan knefisien determinasi, nilai R Square dalam model regresi perusahaan Manufaktur sektor barang knnsumsi diperaleh sebesar 0,560 . Hal ini menunjukkan bahwa besarnya pengaruh variabel independen (perputaran kas, perputaran piutang dan perputaran persediaan) terhadap variabel dependen (return on assets) adalah sebesar 56 \%.. Sedangkan sisanya 44 \% dipengaruhi oleh faktarfaktar lain yang tidak dimasukkan dalam regresi ini.

\section{Saran}

Adapun saran-saran yang dapat diberikan melalui hasil penelitian ini sebagai berikut :

1. Bagi Investor, jika ingin melakukan investasi pada perusahaan manufaktur sektor barang knnsumsi sebaiknya lebih memperhatikan rasio perputaran piutang karena dalam penelitian ini rasia perputaran piutang yang memberikan pengaruh positif signifikan terhadap profitabilitas yang diukur dengan return un asset ( $R \square A$ ) dibandingkan dengan variabel lainnya.

2. Bagi peneliti selanjutnya, sebaiknya menambah variabel lain yang diprediksikan berpengaruh terhadap return an asset, menambah periode penelitian, dan lebih mengkhususkan lagi jenis perusahaan manufaktur sektor barang konsumsinya, jika ingin menjadikan perusahaan manufaktur sebagai objek penelitian.

\section{DAFTAR PUSTAKA}

Al. Haryono Jusup., 2011., Dasar dasar Akuntansi(7 ed.), Yogyakarta: STIE YKPN.

Dilla Ramadani dan Rosyeni Rasyid., 2019, Pengaruh Perputaran Kas, Perputaran Piutang, dan Perputaran Persediaan terhadap Profitabilitas pada Perusahaan Makanan dan Minuman yang terdaftar di Bursa Efek Indanesia Periade 2013-2017, Universitas Negeri Padang.

Ghozali., 2013., Aplikasi Analisis Multivariate Dengan Pragram SPSS, Semarang: Universitas Diponegaro.

Hery., Z0l5., Pengantar Akuntansi (Lamprehensive Editian "Lengkap dengan Kumpulan Saal dan Salusinya"), Jakarta: Grasindo.

Indah Risky Purwaningtias., 2019., Pengaruh Perputaran Modal Kerja, Perputaran Kas, Perputaran Piutang dan Perputaran Persediaan terhadap Profitabilitas Perusahaan Manufaktur Sub Sektar Tekstil dan Garment di BEl periode 2014-2018, Universitas Pancasakti Tegal.

Kasmir., 20I6., Analisis Laparan Keuangan (l ed.), Jakarta: Rajawali Pers.

Lukman Syamsuddin., 2007., Manajemen Keuangan Perusahaan, Jakarta: Raja Grafindo Persada. 
ISSN (print) : 2722-73IG

E-ISSN : 2723-1275

https://ejournal.uhn.ac.id/index.php/humaniora

Nina Sufiana dan Ni Ketut Purnawati., 2013., Pengaruh Perputaran Kas, Piutang, dan Persediaan Terhadap Profitabilitas, Universitas Udayana, Bali,

Purwaningtias, Indah Risky., 2019, Pengaruh Perputaran Modal Kerja, Perputaran Kas, Perputaran Piutang dan Perputaran Persediaan terhadap Profitabilitas Perusahaan Manufaktur Sub Sektar Tekstil dan Garment di BEl periode 2014-2018, Universitas Pancasakti Tegal.

Ramadani, Dilla dan Rasyid, Rosyeni., 2019., Pengaruh Perputaran Kas, Perputaran Piutang, dan Perputaran Persediaan terhadap Profitabilitas pada Perusahaan Makanan dan Minuman yang terdaftar di Bursa Efek Indanesia Periode 2013-2017, Universitas Negeri Padang.

Supriyanta., 2008., Metadalogi Riset Bisnis, Jakarta: PT. Index, Jakarta 